\title{
PENGARUH PENDEKATAN CONTEXTUAL TEACHING AND LEARNING TERHADAP HASIL BELAJAR TEMATIK
}

\author{
Kunthi Zulfa ${ }^{1}$, Agus Budi Santosa ${ }^{2}$, Nanda William ${ }^{3}$ \\ Program Studi Pendidkan Guru Sekolah Dasar STKIP PGRI Trenggalek \\ Email: 'zulfakunthi@gmail.com, ${ }^{2}$ agus.budiku@gmai.com, ${ }^{3}$ williamnanda1@gmail.com
}

\begin{abstract}
ABSTRAK
Peningkatan kualitas pendidikan dapat dilihat dari beberapa faktor yang menunjang. Salah satu tolak ukur peningkatan kualitas pendidikan yaitu kualitas pembelajaran. Banyak sekali masalah yang terjadi dalam proses pembelajaran misalnya peran seorang guru yang sangat dominan (Teacher Center), dan siswa hanya dijadikan sebagai objek dalam proses pembelajaran sehingga kurang tercapainya tujuan dalam suatu pembelajaran. Guru dalam proses pembelajaran harus mengaitkan materi yang disampaikan dengan kehidupan sehari-hari siswa (Contextual Teaching And Learning) supaya siswa lebih aktif dan dapat lebih mudah memahami materi yang disampaikan oleh guru. Tujuan penelitian adalah untuk mendeskripsikan pengaruh Contextual Teaching And Learning terhadap hasil belajar siswa pada pembelajaran tematik kelas IV. Jenis penelitian yang digunakan adalah kuantitatif dengan sifat eksperimen dengan menggunakan One-group pretest-posttest design. Untuk mengetahui pengaruh pendekatan Contextual Teaching And Learning dapat dilakukan dengan cara menghitung dan menggunakan uji t (paired sample $t$ test). Hasilnya menunjukkan bahwa nilai sig. (2-tailed) sebesar $0,000<0,05$, sehingga $\mathrm{H}_{a}$ diterima dan $\mathrm{H}_{0}$ ditolak. Artinya terdapat pengaruh pendekatan Contextual Teaching And Learning Terhadap Hasil Belajar Tematik Siswa Kelas IV SDN 1 Ngepeh Semester Genap Tahun Pelajaran 2019/2020.
\end{abstract}

Kata Kunci : Contextual Teaching And Learning, Hasil Belajar.

\begin{abstract}
Improving the quality of education can be seen from several supporting factors. One measure of improving the quality of education is the quality of learning. There are so many problems that occur in the learning process for example the role of a very dominant teacher (Teacher Center), and students are only used as objects in the learning process so that the goals in a learning process are not achieved. The teacher in the learning process must associate the material presented with students' daily lives (Contextual Teaching And Learning) so that students are more active and can more easily understand the material presented by the teacher. The purpose of this research is to describe the effect of Contextual Teaching And Learning on student learning outcomes in class IV thematic learning. This type of research is quantitative with the nature of the experiment using One-group pretest-posttest design. To determine the effect of the Contextual Teaching And Learning approach can be done by calculating and using t test (paired sample t test). The results show that the value of sig. (2-tailed) of $0,000<0.05$, so Ha is accepted and $\mathrm{HO}$ is rejected. This means that there is an influence of the Contextual Teaching And Learning approach to Thematic Learning Outcomes of Class IV Students of SDN 1 Ngepeh Even Semester of the 2019/2020 Academic Year.
\end{abstract}

Keywords: Contextual Teaching And Learning, Learning Outcomes 


\section{Pendahuluan}

Suatu negara dapat dikatakan maju bisa dilihat dan diukur dari tingginya kualitas sebuah pendidikan yang ada di negara tersebut. Dimana suatu negara yang mengutamakan kualitas dalam pendidikan untuk setiap warga negaranya akan berkembang menjadi negara yang sangat maju dengan tingkat kemakmuran di atas rata-rata. Pendidikan bagi setiap manusia menjadi sebuah kebutuhan yang sangat penting serta akan menjadi penentu berkembang atau tidaknya suatu bangsa ataupun negara. Peningkatan kualitas pendidikan dapat dilihat dari beberapa faktor yang menunjang. Salah satu tolak ukur peningkatan kualitas pendidikan yaitu kualitas pembelajaran. Permasalahan yang sering terjadi di lapangan yaitu permasalahan dalam proses pembelajaran dimana peran seorang guru yang sangat dominan (Teacher Center), dan siswa hanya dijadikan sebagai objek dalam proses pembelajaran sehingga kurang tercapainya tujuan dalam suatu pembelajaran. Guru dalam proses pembelajaran harus mengaitkan materi yang disampaikan dengan kehidupan sehari-hari siswa (Contextual Teaching
And Learning) supaya siswa lebih aktif dan dapat lebih mudah memahami materi yang disampaikan oleh guru.

Menurut Purwanto (dalam Santosa, dkk, 2016:151) mengungkapkan bahwa hasil belajar seringkali digunakan sebagai ukuran untuk mrengetahui seberapa jauh seseorang menguasai bahan yang diajarkam. Menurut Sudjana (dalam Baharun, 2015:39) hasil belajar adalah kemampuan-kemampuan yang dimiliki siswa setelah ia menerima pengalamannya. Sedangkan menurut Rusman (2018:125) hasil belajar adalah sejumlah pengalaman yang diperoleh siswa yang mencakup ranah kognitif, afektif dan psikomotor. Menurut Sanjaya (2016:255), Contextual Teaching And Learning adalah suatu pendekatan pembelajaran yang menekankan kepada proses keterlibatan siswa secara penuh untuk dapat menemukan materi yang dipelajari dan menghubungkanya dengan situasi kehidupan nyata sehingga mendorong siswa untuk dapat menerapkanya dalam kehidupan mereka. Sedangkan Menurut Panjaitan (2018:53) Contextual Teaching and Learning merupakan pendekatan pembelajaran yang memberdayakan siswa. 
Berdasarkan observasi yang dilakukan di SDN 1 Ngepeh, terdapat salah satu guru kelas IV yang dalam pembelajaranya belum menggunakan pendekatan Contextual Teaching And Learning, pada saat proses pembelajaran sebenarnya materi yang disampaikan saat itu sangat sesuai jika guru menggunakan pendekatan Contextual Teaching And Learning yang mengaitkan dengan kehidupan sehari-hari siswa. Menurut Kasmawati (2017) terdapat masalah yang senada yaitu lemahnya proses pembelajaran. Dalam proses pembelajaran, anak kurang didorong untuk mengembangkan kemampuan berpikirnya, dan menjadikan sebuah pelajaran tersebut menjadi bermakna. Proses pembelajaran di dalam kelas hanya diarahkan kepada kemampuan anak untuk menghafal informasi. Selanjutnya menurut Kristin (2016) juga terdapat masalah di lapangan ada beberapa guru yang menggunakan model pembelajaran yang kurang menarik bagi siswa sehingga membuat siswa kurang serius dalam mengikuti pembelajaran di kelas. Guru masih mendominasi dalam proses pembelajaran sehingga siswa hanya pasif saja.
Dengan demikian, maka judul dalam penelitian ini adalah "Pengaruh Pendekatan Contextual Teaching And Learning Terhadap Hasil Belajar Tematik". Adapun batasan masalah dalam penelitian ini yaitu Penelitian dilakukan pada siswa kelas IV SDN 1 Ngepeh Semester Genap Tahun Ajaran 2019/2020, menggunakan pendekatan Contextual Teaching And Learnig, penelitian dilakukan pada Tema 8 "Daerah Tempat Tinggalku" Subtema 2 "Keunikan Daerah Tempat Tinggalku", dan hasil belajar yang diukur adalah pada ranah kognitif. Sedangkan rumusan masalah dalam penelitian ini yaitu "Bagaimana pengaruh pembelajaran Contextual Teaching And Learnig terhadap hasil belajar tematik siswa kelas IV SDN 1 Ngepeh semester genap tahun pelajaran 2019/2020". Metode yang digunakan dalam penelitian ini adalah kuantitatif.

\section{Metode}

Jenis penelitian yang digunakan dalam penelitian ini yaitu penelitian kuantitatif. Sedangkan sifat dari penelitian ini yaitu menggunakan penelitian eksperimen yaitu merupakan metode penelitian percobaan dengan penelitian 
dimaksudkan untuk mengetahui akibat atau dampak suatu kejadian atau variabel yang dihadirkan peneliti. Penelitian ini menggunakan desain Pre-Experimental Design, yang mana dalam desain ini tidak adanya variabel kontrol dan sampel tidak dipilih secara random. Adapun bentuk desainya yaitu One-Group PretestPosttest Design yang digunakan karena terdapat pretest $(\mathrm{O})$, diberi treatment $(\mathrm{X})$ dan diberi posttest. Sehingga hasil perlakuan dapat diketahui lebih akurat, karena dapat membandingkan dengan keadaan sebelum diberi perlakuan. Adapun bentuk One-Group PretestPosttest Design sebagai berikut.

Bagan 1. One-Group Pretest-Posttest Design

$\mathrm{O}_{1} \mathrm{X} \mathrm{O}_{2}$

Sumber: Sugiyono (2018: 115)

Keterangan :

$\mathrm{O}_{1}$ : Nilai pretest (sebelum diberi perlakuan)

$\mathrm{O}_{2}$ : Nilai posttest (setelah diberi perlakuan)

$\mathrm{X}$ : Perlakuan model pembelajaran Number Head Together (NHT)
Penelitian Pre-Experimental OneGroup Pretest-Posttest Design, tahap pertama yaitu menentukan sampel yang akan digunakan dan mengelompokkanya menjadi satu kelas penelitian. Tahap selanjutnya yaitu memberikan pretest untuk mengukur hasil belajar siswa sebelum diberikan treatment pendekatan Contextual Teaching and Learning. Kemudian tahap akhir sampel diberikan posttest untuk mengukur hasil belajar siswa setelah diberikan treatment pendekatan Contextual Teaching and Learning. Tujuan penelitian ini adalah untuk mengetahui pengaruh pendekatan Contextual Teaching and Learning terhadap hasil belajar siswa. Metode pengumpulan data pada penelitian ini, menggunakan metode tes. Menurut Arikunto (2013:193) tes merupakan serentetan pertanyaan atau latihan serta alat lainyang digunakan untuk mengukur ketrampilan, pengetahuan intelegensi, kemampuan atau bakat yang dimilikioleh individu atau kelompok. Bentuk tes yang diberikan adalah tes objektif berbentuk pilihan ganda yang berjumlah 20 item. 
Hasil dan Pembahasan

Penelitian ini dilakukan di SDN 1 Ngepeh pada kelas IV yang berjumlah 27 siswa. Pada penelitian ini seluruh populasi dijadikan sebagai sampel penelitian. Pada awal kegiatan sebelum siswa diberi perlakuan dengan menggunakan pendekatan Contextual Teaching and Learning maka siswa diberikan soal (pretest) berupa pilihan ganda. Pretest dilakukan untuk mengetahui hasil belajar siswa sebelum diberi perlakuan. Setelah diberi perlakuan maka siswa diberi soal (posttest) berupa pilihan ganda untuk mengetahui apakah terdapat perubahan hasil belajar sebelum dan sesudah diberikan perlakuan. Setelah adanya perlakuan maka hasil posttest lebih tinggi dari pada hasil pretest, dapat diartikan nilai rata-rata siswa pada hasil pretest sebesar 60,925, sedangkan nilai rata-rata pada hasil posttest sebesar 74,814. Sehingga dari nilai rata-rata tersebut menunjukkan bahwa hasil posttest mengalami peningkatan yaitu sebesar 13,889 . Berikut diagram perbedaan hasil belajar siswa sebelum dan setelah menggunakan pendekatan Contextual Teaching and Learning.

Diagram 1 Perbedaan Rata-Rata Pretest dan Posttest

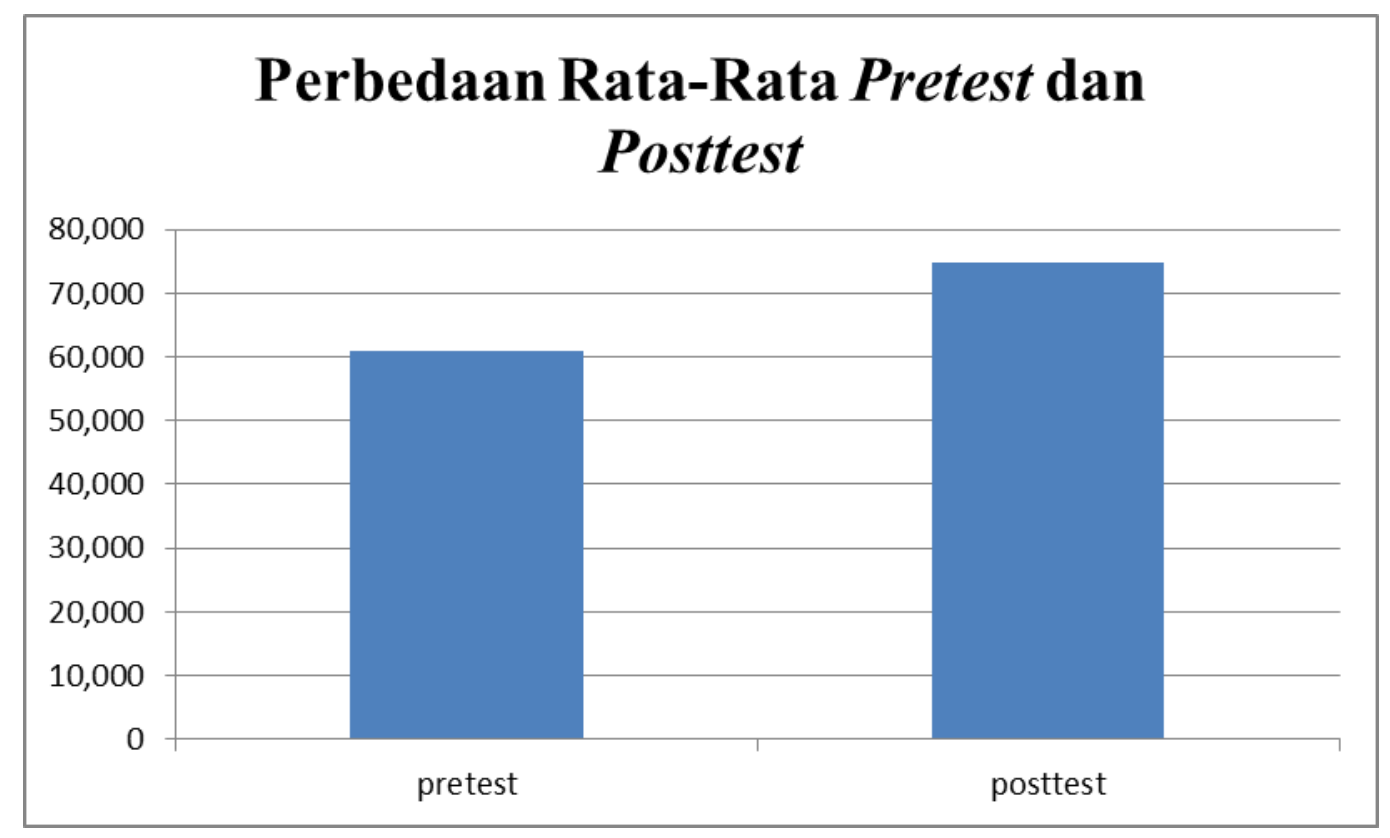


Kunthi Zulfa, dkk.

Dengan demikian dapat disimpulkan bahwa setelah adanya penerapan pendekatan contextual teaching and learning hasil belajar siswa menjadi meningkat. Selanjutnya untuk menganalisi data menggunakan uji normalitas, uji homogenitas, dan uji hipotesis.

berdistribusi normal atau tidak. $\quad U j \mathrm{ji}$ normalitas dilakukan dengan menggunakan uji Shapiro-Wilk dengan menggunakan program SPSS dengan taraf signifikansi 0,05 . Apabila nilai signifikansi tes $>0,05$, maka tes tersebut berdistribusi

normal

1. Uji Normalitas

Uji normalitas dilakukan untuk menentukan apakah data yang diperoleh

Tabel 1 Uji Normalitas

\begin{tabular}{|c|c|c|c|c|c|c|c|}
\hline \multicolumn{8}{|c|}{ Tests of Normality } \\
\hline \multirow{2}{*}{\multicolumn{2}{|c|}{ Kelas }} & \multicolumn{3}{|c|}{ Kolmogorov-Smirnova } & \multicolumn{3}{|c|}{ Shapiro-Wilk } \\
\hline & & Statistic & Df & Sig. & Statistic & $\mathrm{df}$ & Sig. \\
\hline \multirow{2}{*}{$\begin{array}{c}\text { Hasil } \\
\text { Belajar } \\
\text { Siswa }\end{array}$} & Pre-Test & 0.116 & 27 & $.200^{\circ}$ & 0.956 & 27 & 0.292 \\
\hline & Pos-Test & 0.111 & 27 & $.200^{\circ}$ & 0.970 & 27 & 0.599 \\
\hline
\end{tabular}

Berdasarkan output di atas diketahui nilai signifikansi untuk semua data pada uji Shapiro-Wilk > 0,05. Nilai signifikansi Shapiro-Wilk untuk pretest diperoleh nilai $0,292>0,05$. Sedangkan nilai signifikansi Shapiro-Wilk untuk posttest diperoleh nilai signifikansi $0,599>0,05$. Jadi dapat disimpulkan bahwa data hasil belajar siswa berdistribusi normal karena nilai signifikansi $>0,05$.
2. Uji Homogenitas

Uji homogenitas bertujuan untuk mengetahui suatu varian atau keberadaan data dari dua atau lebih kelompok bersifat homogen (sama) atau heterogen (tidak sama). Uji homogenitas dapat dilakukan setelah data persyaratan normalitas terpenuhi yakni data dinyatakan berdistribusi normal. Uji homogenitas dilakukan dengan menggunakan rumus Levene Statistic yang dihitung melalui 
program SPSS 25.0 dengan taraf homogen. Berikut ini hasil output uji signifikansi 0,05 . Apabila nilai signifikansi homogenitas menggunakan SPSS 25.0 $>0,05$ maka distribusi data adalah

Tabel 2 Uji Homogenitas

\begin{tabular}{|c|c|c|c|c|c|}
\hline \multicolumn{6}{|c|}{ Test of Homogeneity of Variance } \\
\hline & & $\begin{array}{l}\text { Levene } \\
\text { Statistic }\end{array}$ & df1 & $\mathrm{df} 2$ & Sig. \\
\hline \multirow{4}{*}{$\begin{array}{l}\text { Hasil } \\
\text { Belajar } \\
\text { Siswa }\end{array}$} & Based on Mean & 2.052 & 1 & 52 & 0.158 \\
\hline & $\begin{array}{c}\text { Based on } \\
\text { Median }\end{array}$ & 1.647 & 1 & 52 & 0.205 \\
\hline & $\begin{array}{c}\text { Based on } \\
\text { Median and with } \\
\text { adjusted df }\end{array}$ & 1.647 & 1 & 47.652 & 0.206 \\
\hline & $\begin{array}{c}\text { Based on } \\
\text { trimmed mean }\end{array}$ & 2.040 & 1 & 52 & 0.159 \\
\hline
\end{tabular}

Berdasarkan output di atas diketahui nilai $T$ Test digunakan untuk mengetahui signifikansi Based on Mean 0,158 > 0,05. pengaruh pendekatan Contextual Sehingga dapat disimpulkan bahwa varian Teaching and Learning terhadap hasil data pretest dan posttest adalah homogen belajar siswa . (sama).

Rumusan Hipotesis:

3. Uji Hipotesis

Setelah dinyatakan kedua kelas homogen dan berdistribusi normal, maka langkah selanjutnya yaitu uji hipotesis. Pengujian hipotesis bertujuan untuk memberikan jawaban apakah dapat diterima atau ditolaknya hipotesis yang diajukan oleh peneliti. Uji hipotesis yang digunakan dalam penelitian ini yaitu Uji Paired Sample T Test. Uji Paired Sample
$\mathrm{H}_{\mathrm{a}}$ : Terdapat pengaruh pendekatan Contextual Teaching and Learning terhadap hasil belajar siswa kelas IV SDN 1 Ngepeh. : Tidak terdapat pengaruh pendekatan Contextual Teaching and Learning terhadap hasil belajar siswa kelas IV SDN 1 Ngepeh. 
Tabel 3 Paired Samples Test

\begin{tabular}{|c|c|c|c|c|c|c|c|c|c|}
\hline \multicolumn{10}{|c|}{ Paired Samples Test } \\
\hline & & \multicolumn{5}{|c|}{ Paired Differences } & \multirow[b]{3}{*}{$\mathrm{t}$} & \multirow[b]{3}{*}{$\mathrm{df}$} & \multirow{3}{*}{$\begin{array}{l}\text { Sig. (2- } \\
\text { tailed) }\end{array}$} \\
\hline & & \multirow[b]{2}{*}{ Mean } & \multirow{2}{*}{$\begin{array}{c}\text { Std. } \\
\text { Deviatio } \\
n\end{array}$} & \multirow{2}{*}{$\begin{array}{l}\text { Std. } \\
\text { Error } \\
\text { Mean }\end{array}$} & \multicolumn{2}{|c|}{$\begin{array}{l}95 \% \text { Confidence } \\
\text { Interval of the } \\
\text { Difference }\end{array}$} & & & \\
\hline & & & & & Lower & Upper & & & \\
\hline $\begin{array}{l}\text { Pai } \\
\text { r } 1\end{array}$ & $\begin{array}{l}\text { postte } \\
\text { st - } \\
\text { pretest }\end{array}$ & $\begin{array}{c}13.888 \\
89\end{array}$ & 8.58592 & $\begin{array}{c}1.652 \\
36\end{array}$ & 10.49241 & 17.28536 & 8.405 & 26 & 0.000 \\
\hline
\end{tabular}

Berdasarkan output pada tabel 4.8 diperoleh nilai sig. (2-tailed) pretest dan posttest 0,000 . Sesuai dengan uji pair sample t-test bahwa nilai sig. (2-tailed) < 0,05 , artinya terdapat perbedaan antara hasil belajar siswa pada data pretest dan posttest. Maka dapat disimpulkan bahwa terdapat pengaruh pendekatan Contextual Teaching and Learning terhadap hasil belajar siswa kelas IV SDN 1 Ngepeh.

Hasil belajar siswa diperoleh melalui pretest untuk mengetahui kemampuan awal siswa sebelum mendapatkan perlakuan dan posttest untuk mengetahui kemampuan akhir siswa setelah mendapatkan perlakuan yang berbeda dalam penyampaian materi. Sebelum tes diberikan kepada kelas yang menjadi sampel penelitian, terlebih dahulu tes diujicobakan pada kelas di luar sampel penelitian yaitu kelas $\mathrm{V}$, karena siswa pada kelas tersebut sudah menerima terdapat perbedaan antara hasil nilai 108 | Autentik: Jurnal Pengembangan Pendidikan Dasar, Vol. 4, No. 2, Tahun 2020 materi di kelas IV. Berdasarkan data hasil penelitian yang sudah dilakukan pada siswa kelas IV di SDN 1 Ngepeh yang berjumlah 27 siswa. Bentuk instrumen tes yang digunakan dalam penelitian ini ganda yang berjumlah 20 item, dengan hasil pretest yang diperoleh rata-rata sebesar 60,925. Dalam mengerjakan pretest siswa mengerjakan soal sesuai dengan pengetahuan yang dimiliki siswa sebelumnya. Setelah kemampuan pretest diperoleh, maka langkah selanjutnya adalah melakukan pembelajaran dengan menerapkan pendekatan Contextual Theaching And Learning, sehingga diperoleh kemampuan posttest dalam menerapkan pendekatan Contextual Theaching And Learning).

Adapun hasil posttest yang diperoleh rata-rata sebesar 74,814 . Maka adalah tes objektif berbentuk pilihan 
pretest dan posttest, yaitu nilai posttest lebih tinggi dibandingkan nilai pretest. Sehingga terdapat pengaruh dalam penerapan pendekatan Contextual Theaching And Learning terhadap hasil belajar pada pembelajaran tematik siswa kelas IV SDN 1 Ngepeh. Berdasarkan hasil uji hipotesis (Uji-t) yang sudah dilakukan bahwa $\mathrm{H}_{\mathrm{a}}$ diterima dan $\mathrm{H}_{0}$ ditolak. Artinya, terdapat pengaruh pendekatan Contextual Theaching And Learning terhadap hasil belajar siswa kelas IV SDN 1 Ngepeh semester genap tahun pelajaran 2019/2020.

Dengan demikian dengan adanya perlakuan menggunakan pendekatan Contextual Teaching And Learning siswa akan lebih mudah memahami materi yang disampaikan karena guru mengaitkan dengan kehidupan sehari-hari siswa. Menurut Sanjaya (2016:255), Contextual Teaching And Learning adalah suatu pendekatan pembelajaran yang menekankan kepada proses keterlibatan siswa secara penuh untuk dapat menemukan materi yang dipelajari dan menghubungkanya dengan situasi kehidupan nyata sehingga mendorong siswa untuk dapat menerapkanya dalam kehidupan mereka. Penelitian sebelumnya dilakukan oleh Maulawi pada tahun 2014 dengan judul "Pengaruh Pendekatan Contextual Teaching And Learning Terhadap Hasil Belajar Siswa Kelas 5 Pada Sistem Pernafasan Manusia". Hasil penelitian menunjukkan terdapat pengaruh Pendekatan Contextual Teaching And Learning Terhadap Hasil Belajar Siswa Kelas 5 Pada Sistem Pernafasan Manusia. Penelitian yang senada dilakukan oleh Gisty pada tahun 2018 dengan judul "Pengaruh Pendekatan Contextual Teaching And Learning Terhadap Hasil Belajar Pada Materi Aritmatika Sosial Dikelas VII Mts Swasta Taman Pendidikan Islam (TPI) Sawit Seberang Tahun Pelajaran 2017/2018".

\section{Kesimpulan}

Berdasarkan hasil dari penelitian yang telah dilakukan di SDN 1 Ngepeh dapat disimpulkan bahwa terdapat perbedaan yang signifikan antara hasil pretest dan posttest menujukkan bahwa nilai rata-rata posttest lebih tinggi dibandingkan dengan nilai rata-rata pretest, hasil analisis hipotesis menggunakan Paired Sample T-Test yang menunjukkan bahwa $\mathrm{H}_{0}$ ditolak yang berarti terdapat perbedaan sebelum dan 
Kunthi Zulfa, dkk.

setelah adanya perlakuan, Hal ini sehari-hari. Bagi siswa, hendaknya aktif menunjukkan bahwa terdapat perbedaan dan bertanggung jawab dalam mengikuti setelah adanya penerapan pendekatan Contextual Teaching and Learning terhadap hasil belajar tematik siswa SDN 1 Ngepeh.

Berdasarkan simpulan di atas, adapun sarannya sebagai berikut yaitu Bagi guru, pendekatan Contextual Teaching and Learning dapat dijadikan sebagai alternatif dalam kegiatan pembelajaran sebagai upaya meningkatkan hasil belajar siswa, dengan pendekatan Contextual Teaching and Learning maka dapat membantu siswa untuk lebih memahami materi yang disampaikan melalui kegiatan secara kegiatan penelitian selanjutnya terutama nyata dan mengaitkanya dalam kehidupan dalam penelitian pendidikan.

\section{DAFTAR PUSTAKA}

Santosa, A., Damayanti, A., Dewi, S. U. 2016. Persepsi Model Pembelajaran Kooperatif Dan Motivasi Berprestasi Terhadap Hasil Belajar Mata Kuliah Bahasa Inggris. Jurnal Dewantara. Vol. 2 No. 2. (September 2016): 148-164, diakses 17 Juli 2020. Journal.stkippgritrenggalek.ic.id/index.php/kid/article/84.

Baharun, Hasan. 2015. Penerapan Pembelajaran Active Learning Untuk Meningkatkan Hasil Belajar Siswa Di Madrasah. Jurnal Pendidikan Pedagogik, Vol. 01 No. 01

Rusman. 2018. Belajar dan Pembelajaran Berbasis Komputer. Bandung: Alfabeta

Sanjaya, Wina. 2016. Strategi Pembelajaran. Jakarta: Kencana.

Panjaitan, D. J. 2018. Peningkatan Pemahaman dan Aplikasi Konsep Melalui Pendekatan Contextual Teaching and Learning. Jurnal MathEducation Nusantara. Vol 1 (1).

110 | Autentik: Jurnal Pengembangan Pendidikan Dasar, Vol. 4, No. 2, Tahun 2020 
Kasmawati. 2017. Pengaruh Model Pembelajaran Contextual Teaching And Learning (CTL) Terhadap Hasil Belajar Siswa Kelas X IPA MAN 1 Makassar. Skripsi tidak diterbitkan. Makassar: Fakultas Tarbiyah Dan Keguruan Universitas Islam Negeri (Uin) Alauddin Makassar.

Kristin, Firosalia. 2016. Analisis Model Pembelajaran Discovery Learning Dalam Meningkatkan Hasil Belajar Siswa Sd. Jurnal Pendidikan Dasar PerKhasa. Volume 2, Nomor 1.

Sugiyono. (2017). Metode Penelitian Pendidikan (Pendekatan Kuantitatif, Kualitatif, dan $R \& D)$. Bandung: Alfabeta.

Arikunto, S. 2013. Prosedur Penelitian Suatu Pendekatan Praktik. Jakarta. Bumi Aksara.

Maulawi, Fathi. 2014. Pengaruh Pendekatan Contextual Teaching And Learning Terhadap Hasil Belajar Siswa Kelas 5 Pada Sistem Pernafasan Manusia. Skripsi tidak diterbitkan. Jakarta: Fakultas IImu Tarbiyah Dan KeguruanUniversitas Islam NegeriSumatera Utara.

Gisty, N. A. 2018. Pengaruh Pendekatan Contextual Teaching And Learning Terhadap Hasil Belajar Pada Materi Aritmatika Sosial Dikelas VII Mts Swasta Taman Pendidikan Islam (TPI) Sawit Seberang Tahun Pelajaran 2017/2018. Skripsi tidak diterbitkan. Medan: Fakultas IImu Tarbiyah Dan KeguruanUniversitas Islam NegeriSumatera Utara. 